\title{
Circulation and suspended sediment dynamics in a tropical estuary under different morphological setting
}

\author{
BÁRBARA P. PAIVA ${ }^{1}$, CARLOS A.F. SCHETTINI ${ }^{1}$, MARÇAL D. PEREIRA ${ }^{2}$, EDUARDO \\ SIEGLE $^{3}$, LUIZ B. MIRANDA ${ }^{3}$ and FERNANDO P. ANDUTTA ${ }^{4}$ \\ ${ }^{1}$ Departamento de Oceanografia, Universidade Federal de Pernambuco/DOcean/UFPE, \\ Av. Arquitetura, s/n, Cidade Universitária, 50740-550 Recife, PE, Brasil \\ ${ }^{2}$ CGGVeritas, CGG International SA, 49 Route de Meyrin, CP 2521211 Genève 28, Switzerland \\ ${ }^{3}$ Instituto Oceanográfico, Universidade de São Paulo/IO/USP, Praça do Oceanográfico, \\ 191, Cidade Universitária, 05508-120 São Paulo, SP, Brasil \\ ${ }^{4}$ Griffith School of Engineering, Griffith University, Gold Coast, QLD 4222, Australia \\ Manuscript received on August 20, 2015; accepted for publication on March 1, 2016
}

\begin{abstract}
Estuarine processes are directly related to the interaction of its forcing conditions with the local morphology. In this study we assess the implications of the opening of a new inlet on the hydrodynamics and suspended sediment concentration (SSC). A set of physical parameters have been measured in the Itanhém river estuary, a small, shallow and mangrove fringed tropical estuary in Northeastern Brazil. Field surveys have been conducted in August 2007 and January 2008, separated by an important morphological change. Our observations show that even shortening the lower estuary channel in $2 \mathrm{~km}$, the inlet opening did not imply in changes in the estuarine circulation. However, SSC increased after the inlet opening. General estuarine circulation showed synodical modulation of tidal asymmetry and residual suspended sediment transport. The estuary showed flood dominance at spring tide and ebb dominance at neap tide. Although not directly changing the estuarine hydrodynamics, the morphological change resulted in an important increase in SSC. This increase might be related to a facilitated import of inner shelf sediment through a shorter channel, having important implications for the estuarine sedimentation processes.
\end{abstract}

Key words: estuarine circulation, sediment fluxes, morphological changes, tidal asymmetry.

\section{INTRODUCTION}

Estuaries are aquatic environments in the continentocean interface where the marine and river water interact with each other. They are semi-enclosed coastal water bodies, with one or more connections with the open sea, where the sea water mix in different ratios with fresh water from the drainage

Correspondence to: Bárbara Pereira Paiva

E-mail: barbara.ppaiva@gmail.com basin. Sea water is driven mostly by the tide and propagates up estuary with flood currents (Pritchard 1955, Cameron and Pritchard 1963, Fairbridge 1980, Dyer 1997).

Tides in the oceans and continental shelves are almost symmetrical, with nearly equal periods of flood and ebb. As tidal waves propagate over shallow waters its asymmetry increases, caused by interactions between wave propagation and 
the bottom and the coast line (Parker 1991). The tidal distortion is increased by lateral constrictions and shallowness in estuaries (Friedrichs and Aubrey 1988, Wright et al. 1999). The tidal asymmetry is the result of non-linear processes, which produces higher frequency tidal constituents of the astronomical tides and can generate flood or ebb dominance (Dronkers 1964, Speer and Aubrey 1985). Tidal asymmetry is intrinsically related to the geomorphologic evolution of estuaries, with economic implications regarding siltation in navigation channels as it is a major factor controlling sediment dynamics (Aubrey and Speer 1985). The effects of tidal asymmetry on sediment transport and budget in estuaries are reported by several studies (Postma 1967, Groen 1967, Dronkers 1985, Aubrey 1986, Ridderinkhof 1997, Van de Kreeke and Dunsbergen 2000, Moore et al. 2009). Flood dominance is characterized by flood phase shorter than ebb phase, and flood dominated systems usually accumulate sediments. On the other hand, in ebb dominated systems the ebb phase is shorter than flood phase, sediment is efficiently transported seawards, and the geometric configuration is usually stable (Speer and Aubrey 1985, Aubrey 1986, Friedrichs and Aubrey 1988).

Small and shallow estuaries may present rapid morphological changes due to sand bank migration, generated by the river flood, alongshore circulation and sediment drift, which may also alter the inlet characteristics. Morphological changes can imply in hydraulic changes and affect the tidal behavior. The Itanhém estuary is a small and shallow tropical estuary, whose inlet morphology changes rapidly, e.g. few years, due to cyclical spit growth and breaching due to longshore drift processes (Cussioli et al. 2011). The study area is located near the Abrolhos Bank, which is the most extensive and the richest system of coral reefs of the South Atlantic Ocean. This complex reef comprises coral reefs, volcanic islands, shallow banks and channels, covering an area of about $6,000 \mathrm{~km}$ (Leão 2002). In

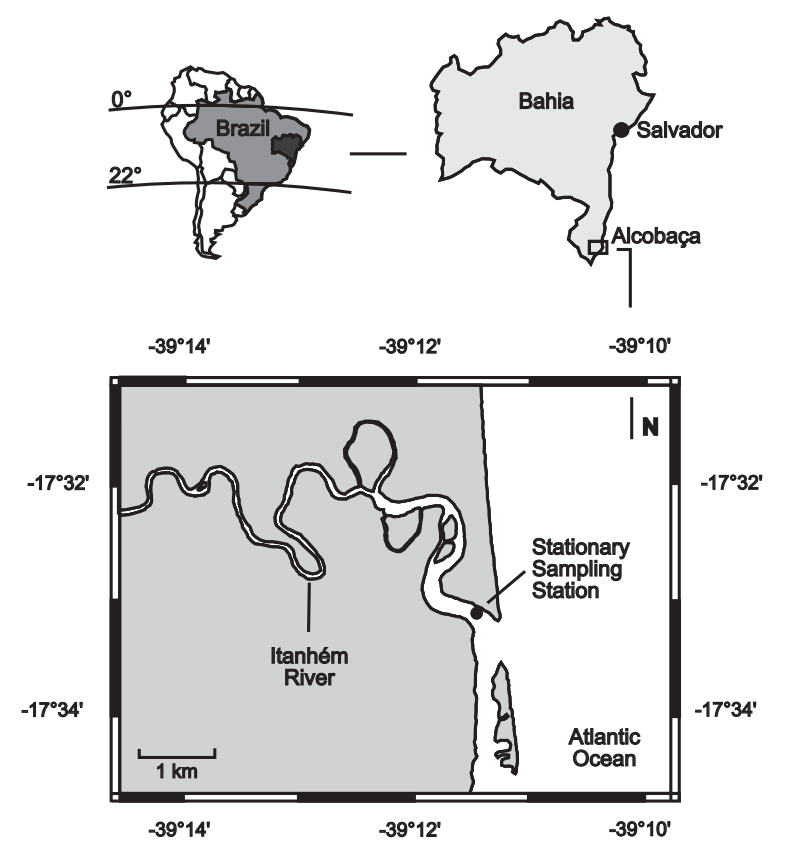

Figure 1 - Study area location in the context of South America and the state of Bahia, indicating the stationary sampling station.

this paper we present an assessment on the estuarine hydrodynamics comparison between two distinct situations: i. when the inlet is located further south, with an approximately $2 \mathrm{~km}$ longer lower estuarine channel; and ii. Spit breaching shortening the estuarine channel. The objective of this paper is to assess the implications of the opening of a new inlet on the hydrodynamics and suspended sediment concentration (SSC). The discussion addresses the tidal asymmetry modulation in the synodical cycle and the potential changes in the estuary-shelf exchanges.

\section{STUDY SITE}

The Itanhém estuary (Figure 1) is located in the south of Bahia State, in the Alcobaça municipality

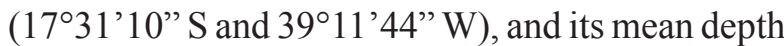
is of about $3 \mathrm{~m}$. The Itanhém river springs are in the state of Minas Gerais, and it runs for about 250 


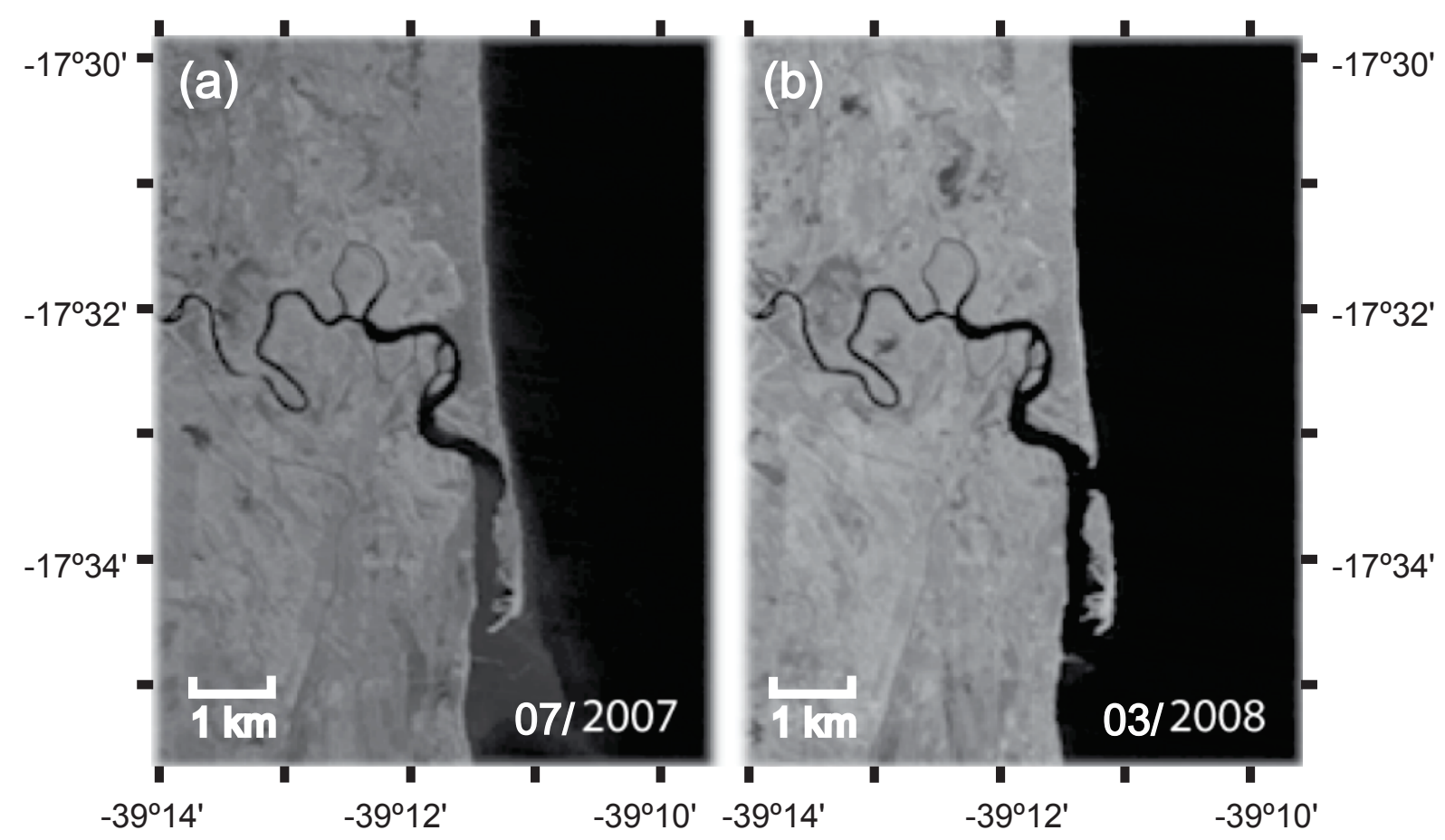

Figure 2 - LANDSAT-5 TM images for the Itanhém estuary in March 2007 (a) and July2008 (b). Adapted from Cussioli et al. (2011).

$\mathrm{km}$ until reaching the ocean (MMA/SRH 1997). The drainage basin has an area of about $5,200 \mathrm{~km}^{2}$ (Schettini et al. 2013).

The climate in the region is tropical wet, with well-defined dry and wet seasons. The dry season occurs between May and September, and the wet season is from October to April. The climatological precipitation rate is $1,600 \mathrm{~mm}^{\text {year }}{ }^{-1}$ (Chaves 1999). The mean freshwater discharge of the Itanhém $r$ is $34.8 \mathrm{~m}^{3} \mathrm{~s}^{-1}$, according to the data set by the Brazilian National Water Agency (ANA). The mean freshwater discharge during the dry and wet seasons is of 28.8 and $66.6 \mathrm{~m}^{3} \mathrm{~s}^{-1}$ (Pereira et al. 2010). Local tides are meso-tidal and semi-diurnal, with form number ranging from 1.1 during neap to 3.0 during spring tide periods (Lessa and Cirano 2006).

The estuarine sediment dynamics has been affected by the upstream land use. Major deforestation occurred during the 1970's, and some estuarine changes have been related to this process (Addad and Martins-Neto 2012). There are still wide areas of mangrove swamps along the estuary, where erosion and accumulation of sediments have been reported by Andrade and Dominguez (2002). The estuarine bed is mainly formed by mud deposits, and sandy material is dominant in the inlet area (Leão 2002).

Cussioli et al. (2011) assessed the morphodynamics of the inlet based on aerial photographs and satellite images. It was observed a cyclical pattern of the spit breaching and growth. In 2007, due to spit breaching at the northern end of the spit, a new inlet was formed nearly $2 \mathrm{~km}$ north of the previous inlet (Figure 2). The inlet dynamics is of particular interest for the region since it affects the local economy, which is strongly based on fishing and tourism (Ribeiro et al. 2000).

To our current knowledge, there is no previous hydrodynamics assessment of the Itanhém estuary, 
although the Caravelas estuary (10 km south) has been extensively investigated (Pereira et al. 2010, Schettini and Miranda 2010, Andutta et al. 2013, Schettini et al. 2013). The Caravelas estuary is a tide dominated system with a negligible fresh water inflow, resulting in a well mixed vertical structure. It is an ebb-dominated system, although the residual suspended sediment transport is upestuary, explained by non-tidal related processes in the adjacent shelf. It shows a complex circulation through a narrow strait that connect it to the Peruípe estuary. Environmental changes in the Caravelas estuary have been assessed by (Sousa et al. 2014) and may have similarities with the neighboring Itanhém estuary.

\section{MATERIALS AND METHODS}

With the aim of covering different hydrological regimes, field data collection were carried out during the dry (August 2007) and wet (January 2008) periods. In each period two 13-hour semi-diurnal tidal experiments were carried out at spring (Aug $29^{\text {th }}$ and Jan $24^{\text {th }}$ ) and neap (Aug $23^{\text {rd }}$ and Jan $17^{\text {th }}$ ) tide periods. Data of water level, current velocity and direction, salinity, temperature and suspended sediment concentration (SSC) were recorded at 0.5 hour intervals in a stationary sampling station in the lower estuary (Figure 1).

Water level was recorded in 2007 using a tidal staff fixed on a pier. In 2008 the water level was recorded with a CTD-logger by RBR model XR-420 fixed on a pier, which recorded also conductivity and temperature at hourly intervals for the period of Jan, $15^{\text {th }}$ until Jan, $24^{\text {th }}$. Current velocity and direction were recorded in 2007 with a direct reading current meter by Valeport model 108 MK-III, with sensors of pressure, conductivity and temperature. In 2008 the current velocity and direction were recorded with an acoustic current meter by Falmouth model 2D-ACM, logged to a computer. The conductivity and temperature were recorded with a CTD-logger by JFE-Advantech model Mini-CTD. The SSC was derived from optical backscattering (OBS) turbidity measurements. The turbidity was recorded with and OBS probe by SeaPoint in 2007, and in 2008 the turbidity was recorded by the OBS probe embedded in the CTDlogger.

Longitudinal surveys were also carried out at each experiment, starting in the estuary mouth and moving up estuary by a fast boat. The surveys lasted approximately one hour each, nearly at highwater. Conductivity, temperature and turbidity were recorded along vertical profiles using a Saiv A/S CTD logger and a SeaPoint OBS probe in 2007, and with a JFE-Advantech mini CTD in 2008.

The data of current and direction were rotated 50 degrees in order to decompose the current in longitudinal and transversal components. We adopted the convention of positive values for flood currents, and negative values for ebb currents.

The SSC data were converted from OBS turbidity records applying conversion equations made by Pereira et al. (2010) for the SeaPoint OBS probe, given by $S S C(O B S)=127.6 O B S+3.8$, and by Schettini et al. (2013) for the JFE-Advantech CTD-logger, given by $S S C(O B S)=1.03 O B S-1.05$.

The water level and the depth-averaged currents were adjusted to the harmonic least square (e.g. Boon and Kiley 1978) in order to weight the role of the tides. The harmonic least square was performed using the $\mathrm{M}_{2}, \mathrm{M}_{4}$, and $\mathrm{M}_{6}$ tidal constituents. Theses constituents were chosen based on the result of the tidal harmonic analysis (T-tide by Pawlowicz et al. 2002) run on the 9-day water level time series available. The comparison between the harmonic and observed signals was with Willmott's (1981) skill assessment. The averaged agreement for water level was $97 \%$, and the averaged agreement for the currents was $95 \%$.

Historical river discharge data for the Itanhém $r$ were obtained from the HIDROWEB database (gauge station \#55490000, Brazilian Water Agency 
(ANA)), since 1970 until present. River discharge during the surveyed periods was also directly measured using currentmeters at a cross section above the upper limit of tidal wave propagation (Pereira et al. 2010).

\section{RESULTS}

In order to present the main differences between both surveys, conducted under different morphological settings, results are presented in a comparative manner, with 2007 (Figures 3 and 4) representing the longer estuarine channel and 2008 (Figures 5 and 6) the post spit breaching situation. Table I shows the summary of the surveyed parameters over each period. Sampling periods were nearly the same, covering similar tide characteristics. Water level differences between the beginning and final of each survey associated to semi-diurnal inequalities are observed in all surveys, reaching up to -0.4 $\mathrm{m}$ for the 2008 spring tide survey. Flood and ebb duration proportions were about the same for the neap tide surveys, while for the spring tide surveys the ebb accounted with more than $60 \%$ of the tidal

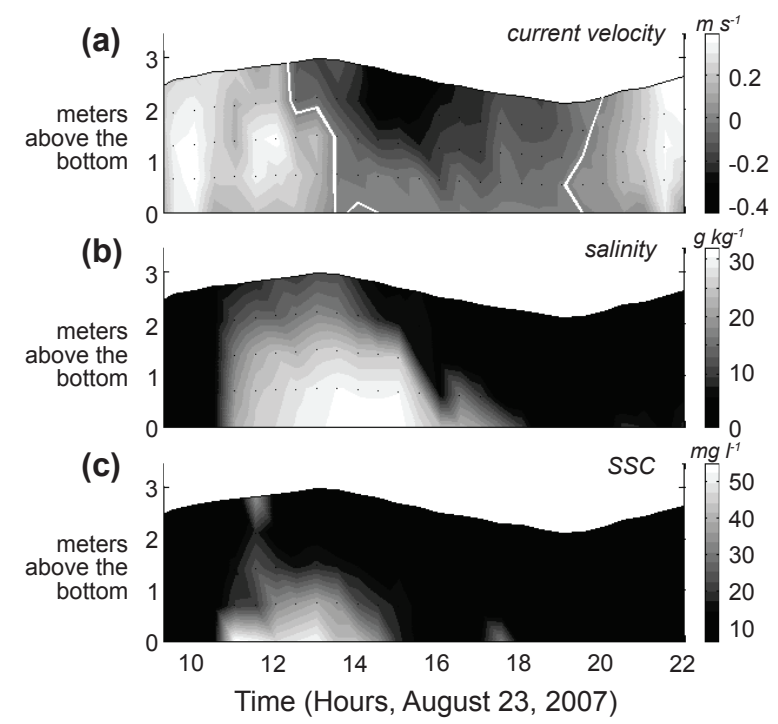

Figure 3 - Temporal and vertical distribution of current velocity (a, flood $+/$ ebb -) in $\mathrm{m} \mathrm{s}^{-1}$, salinity (b) in $\mathrm{g} \mathrm{kg}^{-1}$ and $\mathrm{SSC}$ (c) in $\mathrm{mg} \mathrm{l}^{-1}$ during the 2007 neap tide survey. period. Averaged flood and ebb currents during the neap tidal surveys were nearly equivalent, while there was flood dominance at the 2007 spring tidal survey but not in 2008 survey.

Maximum neap tide flood currents were similar between the surveys of different years, as well as spring tidal flood currents. On the other hand, the maximum ebb currents were different, with the 2008's currents being of about $0.2 \mathrm{~m} \mathrm{~s}^{-1}$ higher than the 2007 ones. The salinity variation within each survey was similar of about $30 \mathrm{~g} \mathrm{~kg}^{-1}$, although the mean salinity values in the 2008 surveys were higher than the 2007 ones. The SSC values were of the order of tens of $\mathrm{mg}^{-1}$ in all surveys, therefore the higher mean values were recorded in the 2008 surveys.

The time series of water level and salinity recorded between Jan 15 and 24, 2008 are shown in Figure 7. The tidal range varies between $1 \mathrm{~m}$ at the beginning of the series, at neap tide, and increase up to $1.7 \mathrm{~m}$ at spring tide. The salinity variation follows the water level variation, although it did not present a clear change in the range of variation.

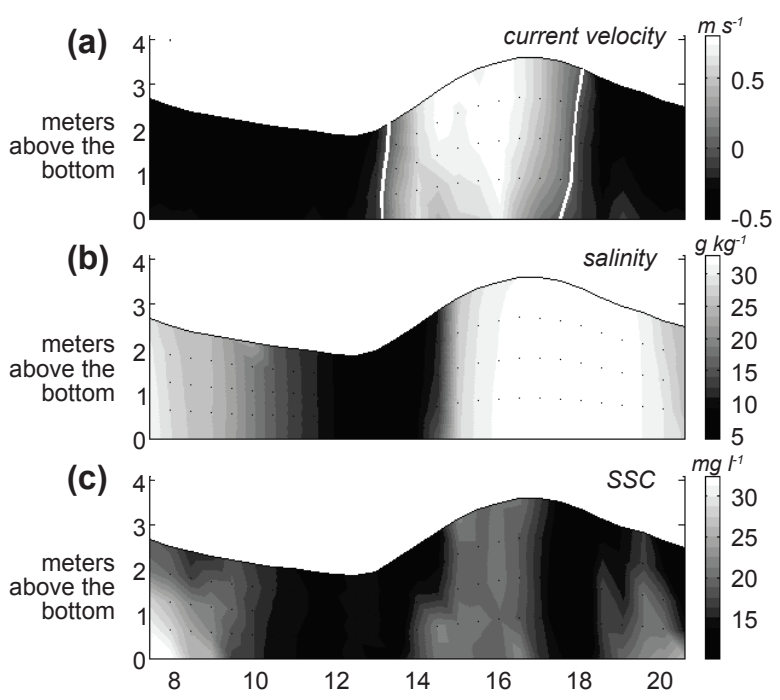

Figure 4 - Temporal and vertical distribution of current velocity (a, flood +/ ebb -) in $\mathrm{m} \mathrm{s}^{-1}$, salinity (b) in $\mathrm{g} \mathrm{kg}^{-1}$ and $\mathrm{SSC}$ (c) in $\mathrm{mg} \mathrm{l}^{-1}$ during the 2007 spring tide survey. 
TABLE I

Summary of the time frame, tidal characteristic and current velocity, salinity and SSC maximum, minimum and mean values of the tidal surveys. $\delta$ : water level difference between the beginning and end of survey. F/E: percentage of flood and ebb duration; $U_{\text {avg }}$ : averaged flood and ebb current velocity. $Q_{S E D}$ : sediment flux.

\begin{tabular}{|c|c|c|c|c|}
\hline & \multicolumn{2}{|c|}{2007} & \multicolumn{2}{|c|}{2008} \\
\hline & $\begin{array}{c}\text { Neap } \\
\text { Aug } \mathbf{2 3}^{\text {rd }}\end{array}$ & $\begin{array}{c}\text { Spring } \\
\text { Aug } 29^{\text {th }}\end{array}$ & $\begin{array}{c}\text { Neap } \\
\text { Jan } 17^{\text {th }}\end{array}$ & $\begin{array}{c}\text { Spring } \\
\text { Jan } 24^{\text {th }}\end{array}$ \\
\hline Duration (h) & 12.8 & 13.0 & 13.0 & 13.0 \\
\hline Tidal Range (m) & 0.87 & 1.73 & 1.08 & 1.69 \\
\hline$\delta \mathrm{z}(\mathrm{m})$ & 0.16 & -0.16 & -0.06 & -0.41 \\
\hline $\mathrm{F} / \mathrm{E}(\%)$ & $51.8 / 48.2$ & $33.6 / 66.4$ & $49.5 / 50.5$ & $37.4 / 62.6$ \\
\hline Flood $U_{\text {avg }}\left(\mathrm{m} \mathrm{s}^{-1}\right)$ & 0.19 & 0.52 & 0.27 & 0.46 \\
\hline $\operatorname{Ebb} \mathrm{U}_{\mathrm{avg}}\left(\mathrm{m} \mathrm{s}^{-1}\right)$ & -0.13 & -0.33 & -0.30 & -0.47 \\
\hline Flood $U_{\max }\left(\mathrm{m} \mathrm{s}^{-1}\right)$ & 0.39 & 0.80 & 0.52 & 0.84 \\
\hline $\operatorname{Ebb} \mathrm{U}_{\max }\left(\mathrm{m} \mathrm{s}^{-1}\right)$ & -0.44 & -0.50 & -0.65 & -0.74 \\
\hline $\mathrm{U}_{\text {mean }}\left(\mathrm{m} \mathrm{s}^{-1}\right)$ & 0.05 & -0.04 & -0.05 & -0.13 \\
\hline $\mathrm{S}_{\max }\left(\mathrm{g} \mathrm{kg}^{-1}\right)$ & 31.95 & 32.88 & 36.39 & 35.88 \\
\hline $\mathrm{S}_{\min }\left(\mathrm{g} \mathrm{kg}^{-1}\right)$ & 0.88 & 4.54 & 1.42 & 6.90 \\
\hline $\mathrm{S}_{\text {mean }}\left(\mathrm{g} \mathrm{kg}^{-1}\right)$ & 10.10 & 22.52 & 20.66 & 28.12 \\
\hline $\mathrm{SSC}_{\text {Max }}\left(\mathrm{mg} \mathrm{l}^{-1}\right)$ & 54.84 & 32.51 & 78.88 & 51.94 \\
\hline $\mathrm{SSC}_{\min }\left(\mathrm{mg} \mathrm{l}^{-1}\right)$ & 6.35 & 10.18 & 7.12 & 8.27 \\
\hline $\mathrm{SSC}_{\text {mean }}\left(\mathrm{mg} \mathrm{l}^{-1}\right)$ & 13.69 & 17.01 & 31.51 & 23.58 \\
\hline $\mathrm{Q}_{\mathrm{SED}}\left(\mathrm{kg} \mathrm{s}^{-1}\right)$ & -112.3 & 76.3 & -388.3 & 836.3 \\
\hline
\end{tabular}

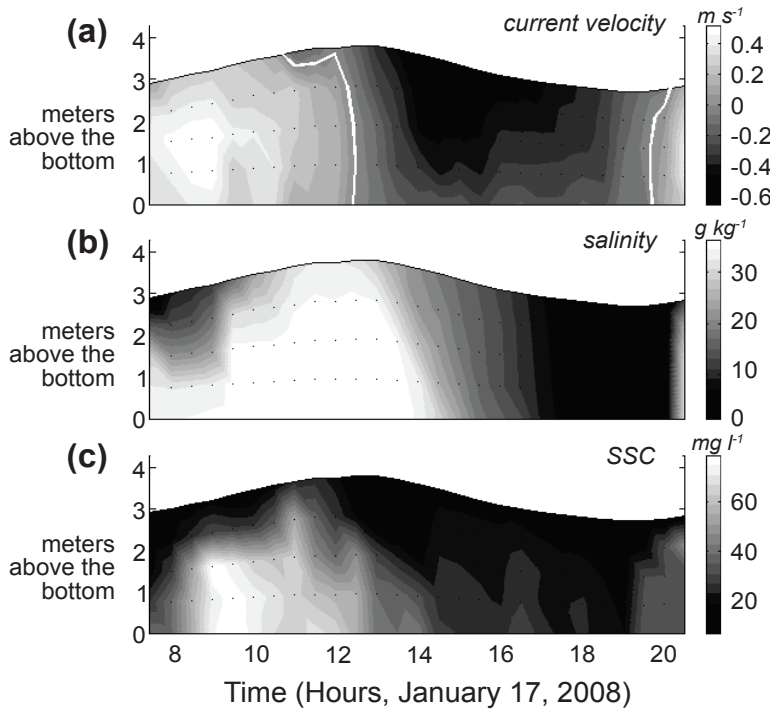

Figure 5 - Temporal and vertical distribution of current velocity (a, flood $+/$ ebb -) in $\mathrm{m} \mathrm{s}^{-1}$, salinity (b) in $\mathrm{g} \mathrm{kg}^{-1}$ and SSC (c) in $\mathrm{mg}^{-1}$ during the 2008 neap tide survey.
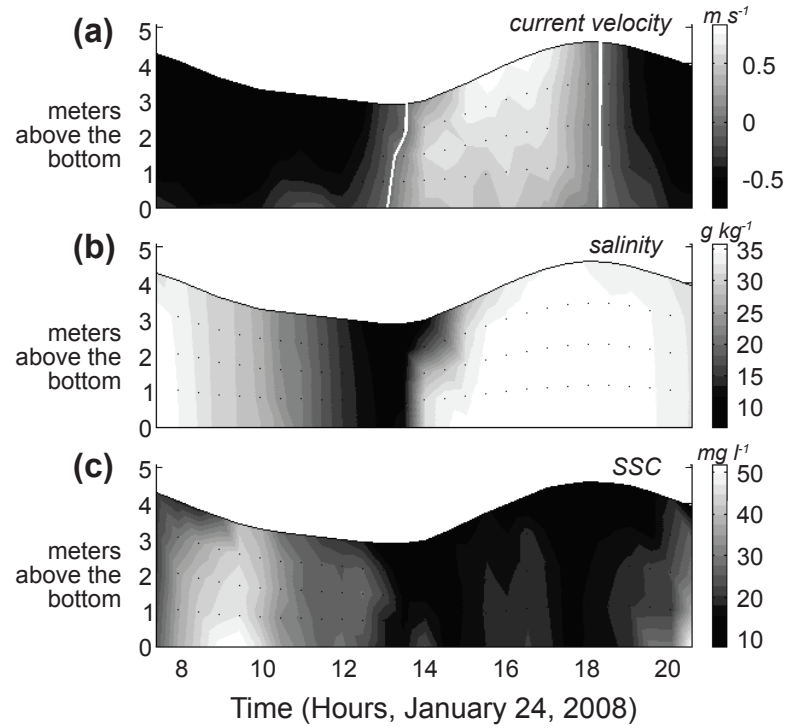

Figure 6 - Temporal and vertical distribution of current velocity (a, flood $+/$ ebb -) in $\mathrm{m} \mathrm{s}^{-1}$, salinity (b) in $\mathrm{g} \mathrm{kg}^{-1}$ and $\mathrm{SSC}$ (c) in $\mathrm{mg}^{-1}$ during the 2008 spring tide survey. 

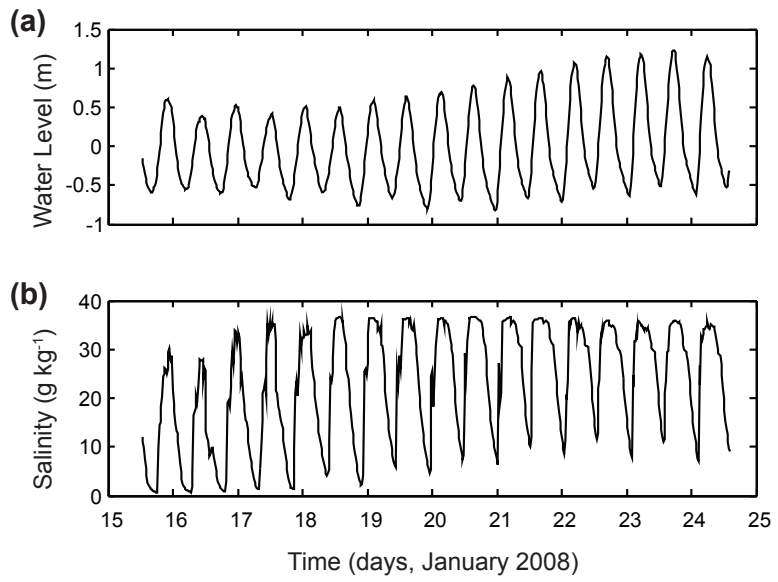

Figure 7 - Time series of tidal oscillation (a) and salinity (b) recorded during the 2008 campaign by the instruments fixed on a pier.

During all period the salinity variability in a tidal period was of about $30 \mathrm{~g} \mathrm{~kg}^{-1}$. The general pattern of the salinity time series, resembling triangular shapes, being flattened at higher salinities, suggests the advection of water fronts.

Figure 8 shows the time-average vertical profiles of current velocity and salinity of each survey. Both neap tide surveys showed residual seawards currents at surface and landwards nearbottom currents. Both spring tide surveys showed unidirectional seaward flow. The time-averaged salinity profiles during neap tides were highly stratified with salinity difference of about 10 $\mathrm{g} \mathrm{kg}^{-1}$ in the water column. At spring tides, the stratification was reduced to 1 and $4 \mathrm{~g} \mathrm{~kg}^{-1}$ for the 2007 and 2008 surveys, respectively.

The results from the longitudinal surveys for salinity and SSC are shown in terms of depthaveraged values in Figure 9 and Table II. The salinity distribution showed a dilution pattern landwards in all surveys. The salt intrusion was scaled by the length between the inlet and the maximum extension of the isohalines of 2 and 30 $\mathrm{g} \mathrm{kg}^{-1}$ (according to Schettini and Truccolo 1999). The salt intrusion length of the salinity of $30 \mathrm{~g} \mathrm{~kg}^{-1}$ for the 2008 neap tide campaign was not observed
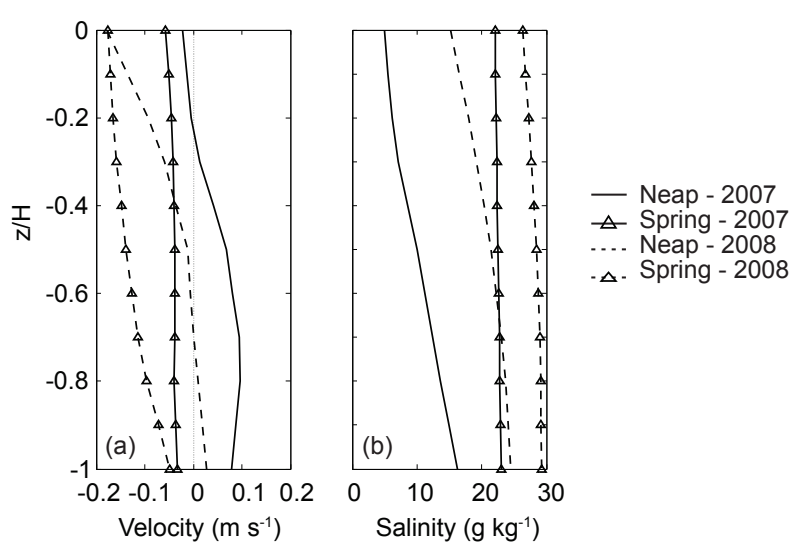

Figure 8 - Time-averaged vertical profiles of current velocity (left panel, flood $+/$ ebb -) and salinity (right panel) at the four surveys of 2007 and 2008.

within the estuary, since the salinity registered at the inlet was of about $23 \mathrm{~g} \mathrm{~kg}^{-1}$. All surveys aimed to reach the upper estuary, when freshwater was observed in the whole water column. The rate of salinity change $(\partial \mathrm{s} / \partial \mathrm{x})$ was almost the same for the two 2007 surveys. For the 2008 surveys, this rate was $50 \%$ higher during spring tide than during neap tide.

Due to logistic restrictions, the $\mathrm{SSC}$ longitudinal distribution for the spring tide of 2007 has not been collected. The SSC longitudinal distribution for the neap tide of 2007 presented the highest values of about $40 \mathrm{mg}^{-1}$ close to the inlet, decreasing landwards steeply to $10 \mathrm{mg} \mathrm{l}^{-1}$ and remaining at this value up estuary. The SSC longitudinal distributions of both surveys of 2008 were relatively similar, with the SSC varying between 15 and $25 \mathrm{mg} \mathrm{l}^{-1}$ from the mouth up to 9 $\mathrm{km}$ up estuary. After this point, the SSC during the spring tide survey increased up to $80 \mathrm{mg} \mathrm{l}^{-1}$ and decreased again, remaining at $40 \mathrm{mg} \mathrm{l}^{-1}$.

\section{DISCUSSION}

The sampling strategy of the present study was initially designed to assess the synodical and seasonal variability of the estuary hydrodynamics, 
TABLE II

Summary results from the longitudinal profiles (Figure 9). $\partial \mathrm{s} / \partial \mathrm{x}$ : longitudinal salinity gradient $\left(\mathrm{g} \mathrm{kg}^{-1} \mathbf{k m}^{-1}\right) ; \mathbf{L}_{30}-\mathbf{s a l t}$ intrusion length of the salinity of $30 \mathrm{~g} \mathrm{~kg}^{-1} ; \mathrm{L}_{2}-$ salt intrusion length of the salinity of $2 \mathrm{~g} \mathrm{~kg}^{-1}$.

\begin{tabular}{ccccc}
\hline & \multicolumn{2}{c}{$\mathbf{2 0 0 7}$} & \multicolumn{2}{c}{$\mathbf{2 0 0 8}$} \\
\hline$\partial \mathrm{s} / \partial \mathrm{x}\left(\mathrm{g} \mathrm{kg}^{-1} \mathrm{~km}^{-1}\right)$ & Neap & Spring & Neap & Spring \\
\hline $\mathrm{L}_{30}(\mathrm{~km})$ & 2.7 & 2.8 & 2.1 & 3.1 \\
\hline $\mathrm{L}_{2}(\mathrm{~km})$ & 0.5 & 5.0 & - & 7.0 \\
\hline
\end{tabular}
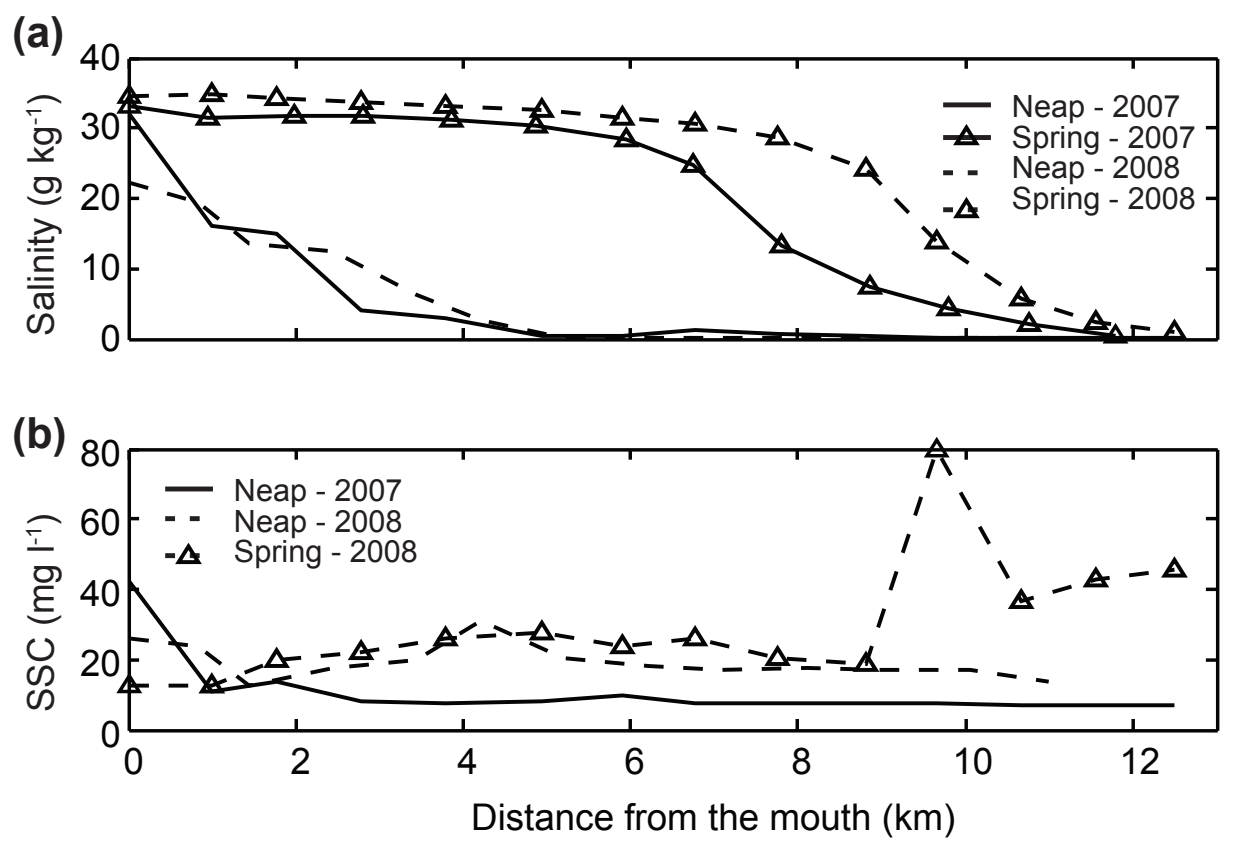

Figure 9 - Longitudinal distribution of depth-averaged salinity (a) and SSC (b).

the latter aiming to identify the changes due to the river discharge at dry and wet periods. However, since the 2008 rainy season was delayed, the mean river discharge of August 2007 and January 2008 were nearly identical, of 22.0 and $22.8 \mathrm{~m}^{3} \mathrm{~s}^{-1}$, respectively. Based on historical records (19702012), it was expected that the river discharge at the wet season would be of about 2.5 times higher than at dry period (Pereira et al. 2010). On the other hand, there was a major estuarine morphology change between the 2007 and 2008 campaigns. A new inlet was naturally opened through the breach of the longshore spit that fronts the estuary, shortening the channel length in about $2 \mathrm{~km}$ (Figure 2 ), which implies in a change of approximately $10 \%$ in the estuary length.

This morphological change did not produce noticeable changes in the tidal behavior. The tidal 
asymmetry remains nearly the same when scaled by the ratio between the periods of flood and ebb at the neap (1.06 and 1.0) and spring (0.51 and 0.59) tides. Further, the currents at both neap tides showed ebb dominance, shifting to flood dominance at spring tides. Changes in the estuarine morphology implying in changes in its hydrodynamics has been reported by several authors (e.g. Furukawa and Wolanski 1996, Moore et al. 2009, Brown and Davies 2010). The periodical sediment displacement landwards during the flood and seawards during the ebb are driven by non-linear process related to the flow yield shear stress and sediment transport thresholds, intrinsically related to the tidal behavior in the estuarine basin (Dyer 1995). Alterations on the channel geometry and depth will affect the tidal behavior in the estuarine basin, producing tidal asymmetries or even inverting the existing asymmetry pattern (Wang et al. 2002, Jiang et al. 2012). The shortening of the Itanhém estuary is a cyclical process related to the longshore sediment transport, spit growth and breaching (Cussioli et al. 2011), but from our observations this process is not producing noticeable changes in the tidal wave propagation into the estuary.

Ebb dominance can be explained based on the relationship between the channel volume and intertidal areas of volume storage in the mangrove swamps (Friedrichs and Aubrey 1988, Mazda et al. 1995, Blanton et al. 2002). Flood dominance can be explained by the tidal propagation in shallow waters (Dronkers 1986, Friedrichs and Aubrey 1988), which is emphasized by the shortening of the flood period in respect to the ebb period. The dominance shift between neap and spring tides indicates that the estuary is in an intermediate condition between the morphological effects (storage volume) and the tidal deformation. Dronkers (1998) derived an asymmetry index based on estuarine morphological equilibrium, given by

$$
\gamma=\left[\frac{H+a}{H-a}\right]^{2} \cdot \frac{S_{L W}}{S_{H W}}
$$

Where $a$ is the tidal amplitude, $H$ is the depth, $S_{L W}$ and $S_{H W}$ are the free surface areas at low and high water. If $\gamma \approx 1$ indicates the tide is symmetrical; $\gamma$ $>1$ indicates flood dominance, and $\gamma<1$ indicates ebb dominance. The $\left[\frac{H+a}{H-a}\right]$ parameter weights the shallow water nonlinearities, while the ratio $\frac{S_{L W}}{S_{H W}}$ stands for the intertidal volume storage. Scaling this quantities, $H \sim 3 \mathrm{~m}$; the $S_{L W}$ can be reasonably given by the free surface area at low tide from $(\sim$ $1.9 \mathrm{~km}^{2}$ ), and the $S_{H W}$ can be estimated based on the mangrove swampy areas, linearly related to the tidal height . These values ranged between 2.4 and $3 \mathrm{~km}^{2}$, during neap and spring tide respectively. The values of $\gamma$ for neap tide were 0.8 and 0.9 , and 1.3 and 1.2 for spring tide, which agree with the currents observations. The estuary shortening has little effect on intertidal water storage. Major changes would be expected in the tidal distortion, which would lead to the intensification of the ebb dominance. Therefore this was not observed. Thus, it is likely the tidal distortion is occurring mostly in the shelf. The local shelf width is more than $100 \mathrm{~km}$ wide due to the presence of Abrolhos Bank.

In order to investigate the estuarine structure associated with the salt stratification and mixing we summarize the results through the horizontal Richardson number $R\left(R i_{H}\right)$. This dimensionless number (also called Simpson number) weights the relative effects of the buoyancy flux in enhancing the stratification to the tidal mixing in destroying it (Geyer and MacCready 2014):

$$
R i_{H}=\frac{-g \beta \frac{\partial s}{\partial x} H^{2}}{c_{D} U_{T}^{2}}
$$

where $\beta$ is the saline contraction coefficient $(\approx$ $\left.7.710^{-4}\right), s$ is the salinity, $x$ is the longitudinal distance, $H$ is the estuarine depth, $C_{D}$ is the drag coefficient $\left(\approx 2.510^{-3}\right)$, and $U_{T}$ is the amplitude of tidal currents. The buoyancy flux is indicated by the longitudinal gradient of salinity $(\partial s / \partial x)$ $(\partial s / \partial x)$ in the numerator, while the mixing effects 
are mainly scaled by tidal currents amplitude in the denominator. The $R i_{H}$ for the neap and spring campaigns of 2007 were 0.6 and 0.4 , respectively, and 0.9 and 0.6 for the 2008 campaigns, in the same order. As expected, the $R i_{H}$ at neap tides were higher than the ones in spring tides. Also, the values found for the 2008 surveys were slightly higher than those for 2007. Although these results are very limited, this may indicate the increasing role of the river discharge when reducing the length (and volume) of the estuary. Notwithstanding, $R i_{H}$ values can vary two orders of magnitude $(0.1-10)$, the small range of our results suggests rather little or no significant changes in the estuarine dynamics, and the former statement would require a more careful approach. The conditions sampled indicated that the Itanhém estuary is "time-dependent saltwedge" type, according the classification proposed by (Geyer and MacCready 2014). This classification is based on the freshwater Froude number $\left(F r_{f}\right)$ and mixing number $(M)$. Considering all the four surveys, $F r_{f}$ ranged from 0.21 to 0.07 at Itanhem $r$, while $M$ ranged from 1.17 to 0.95 .

The major changes observed between the 2007 and 2008 campaigns were the increase in the SSC, which nearly doubled in terms of mean values from $\sim 15$ to $\sim 30 \mathrm{mg} \mathrm{l}^{-1}$, and consequently the resulting sediment fluxes. The fluxes' direction remained the same, seawards at neap and landwards at spring tides but increased by a factor of three and ten, respectively, from 2007 to 2008 (Table I). The intratidal variation in the SSC changed between neap and spring tides with a repeated pattern in 2007 and 2008. The higher SSC at neap tides were recorded at $\mathrm{HW}$ associated with salty waters, while the higher SSC at spring tides were recorded during the ebb. Although, in all surveys the higher values of SSC were associated with saline waters (Figure 10), which is a pattern also reported for the nearby Caravelas estuary (Schettini and Miranda 2010, Schettini et al. 2013). In spite of the Itanhém estuary having a larger drainage basin and sediment

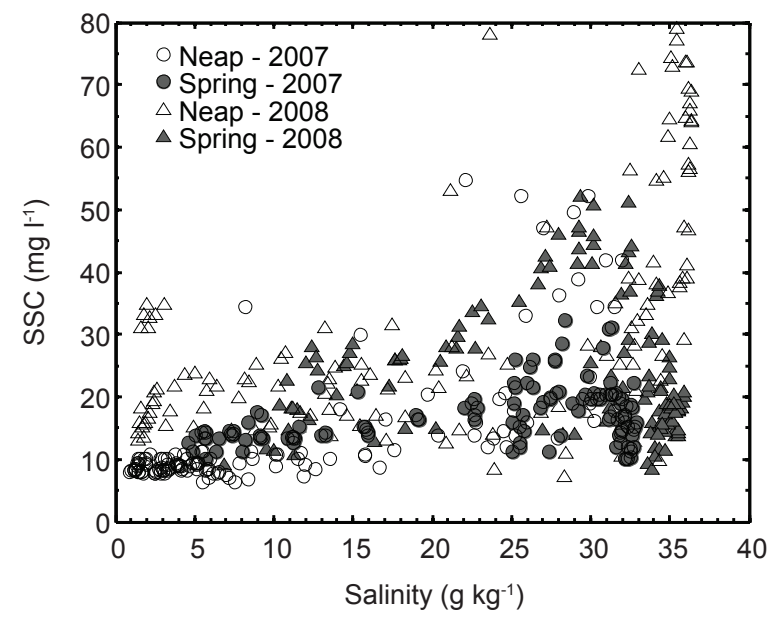

Figure 10 - Correlation between SSC ( $\mathrm{mg} \mathrm{l}^{-1}$ ) and salinity (g $\left.\mathrm{kg}^{-1}\right)$ at the stationary sampling station at the four tidal surveys.

load, when compared to the Caravelas estuary, the SSC range in the order of tens of $\mathrm{mg}^{-1}$ reaching the hundreds only during flood events. In contrast, the inner shelf SSC is likely to reach values above hundreds of $\mathrm{mg}^{-1}$ due to the wind wave action along the shore. Under this scenario, the estuary shortening would imply in the closeness of the shelf SSC source, resulting in the intensification of fine sediment dynamics. Since the processes of the sand bar opening is cyclical and occurs at a time scale of a few years (Cussioli et al. 2011), it may be possible that these events can be recorded in the intertidal mangrove areas in the lower estuary in terms of sedimentation rates.

\section{CONCLUSIONS}

Results of hydrographic campaigns performed at an estuary under different morphological conditions indicated that its general circulation is not much affected. We were able to repeat the field surveys before and after the natural breaching of the longshore sand spit that controls the estuarine inlet. This opening resulted in the shortening of the lower estuarine channel in $2 \mathrm{~km}$. The estuary showed a synodical modulation between flood dominance at 
spring tides and ebb dominance at neap tides, in accordance to Dronkers' (1998) asymmetry index. There was also a synodical modulation of the suspended sediment residual transport, seawards at neap tide and landwards at flood tides. Although not directly changing the estuarine hydrodynamics, the morphological change resulted in an important increase in SSC. This increase might be related with a facilitated import of inner shelf sediment through a shorter channel, having important implications for the estuarine sedimentation processes.

\section{ACKNOWLEDGMENTS}

Data were collected with the help of numerous people, whose we are thankful for their assistance during field work. This is a contribution of the ProAbrolhos Project funded by Conselho Nacional de Desenvolvimento Científico e Tecnológico (CNPq), through the Program Instituto do Milênio PROABROLHOS, CNPq \#420219/2005-6. C.A.F.S. and E.S. acknowledge the support through CNPq Research Fellowships (308665/2013-9 and 304975/2012-5).

\section{REFERENCES}

ADDAD J AND MARTINS-NETO MA. 2012. Deforestation and Coastal Erosion: A Case from East Brazil. J Coast Res 16: 423-431.

ANDRADE ACDS AND DOMINGUEZ JML. 2002. Informações geológico-geomorfológicas como subsídios à análise ambiental: o exemplo da planície costeira de Caravelas-Bahia. Bol Parana Geociências 51: 9-17.

ANDUTTA FP, MIRANDA LB, SCHETTINI CAF, SIEGLE E, SILVA MP, IZUMI VM AND CHAGAS FM. 2013. Temporal variations of temperature, salinity and circulation in the Peruípe river estuary (nova Viçosa, BA). Cont Shelf Res 70: 36-45.

AUBREY DG. 1986. Hydrodynamic controls on sediment transport in well-mixed bays and estuaries. In: van de Kreeke J (Ed), Physics of Shallow Estuaries and Bays. Springer, Berlin, p. 245-258.

AUBREY DG AND SPEER PE. 1985. A study of non-linear tidal propagation in shallow inlet/estuarine systems Part I: Observations. Estuar Coast Shelf Sci 21: 207-224.

BLANTON JO, LIN G AND ELSTON SA. 2002. Tidal current asymmetry in shallow estuaries and tidal creeks. Cont Shelf Res 22: 1731-1743.
BOON III JD AND KILEY KP. 1978. Harmonic analysis and tidal prediction by the method of least squares. VIMS Spec Rep Appl Mar Sci Ocean Eng 186: 49.

BROWN JM AND DAVIES AG. 2010. Flood/ebb tidal asymmetry in a shallow sandy estuary and the impact on net sand transport. Geomorphology 114: 431-439.

CAMERON WM AND PRITCHARD DW. 1963. Estuaries. In: Hill MN (Ed), The sea: ideas and observations on progress in the study of the seas. Interscience, New York, p. 306-324.

CHAVES RR. 1999. Variabilidade da precipitação na Região Sul do Nordeste e sua associação com padrões atmosféricos. Rev Bras Geofísica 17(2-3): 220.

CUSSIOLI MC, SIEGLE E, MIRANDALB AND SCHETTINI CAF. 2011. Morphodynamics at the Itanhém inlet. In: Coastal Sediments, 2011, Miami. Coastal Sediments 2011 Papers, Miami, p. 1-13.

DRONKERS J. 1985. Tide-induced residual transport of fine sediment. In: van de Kreek J (ed) Physics of Shallow Estuaries and Bays. Lecture Notes on Coastal and Estuarine Studies, Volume 16. Springer, New York, p. 228-244.

DRONKERS J. 1986. Tidal asymmetry and estuarine morphology. Netherlands J Sea Res 20: 117-131.

DRONKERS J. 1998. Morphodynamics of the Dutch Delta. In: Dronkers J and Scheffers MBAM (Eds), Physics of Estuaries and Coastal Seas. Balkema, Rotterdam, p. 297-304.

DRONKERS JJ. 1964. Tidal computations in rivers and coastal waters. North Holland Publishing, Amsterdam, Interscience (Wiley), New York, p. 518.

DYER KR. 1995. Sediment transport processes in estuaries. In: Perillo GME (Ed), Geomorphology and sedimentology of estuaries. Elsevier, New York, p. 423-449.

DYER KR. 1997. Estuaries: a physical introduction, $2^{\text {nd }}$ ed., J Wiley \& Sons, New Jersey, p. 210.

FAIRBRIDGE RW. 1980. The estuary: its definition and geodynamic cycle. In: Olausson E and Cato I (Eds), Chemistry and biogeochemistry of estuaries. J Wiley \& Sons, New York, p. 1-35.

FRIEDRICHS CT AND AUBREY DG. 1988. Non-linear tidal distortion in shallow well-mixed estuaries: a synthesis. Estuar Coast Shelf Sci 27: 521-545.

FURUKAWA K AND WOLANSKI E. 1996. Sedimentation in Mangrove Forests. Mangroves Salt Marshes 1: 3-10.

GEYER WR AND MACCREADY P. 2014. The Estuarine Circulation. Annu Rev Fluid Mech 46: 175-197.

GROEN P. 1967. On the residual transport of suspended matter by an alternating tidal current. Netherlands J Sea Res 3: 564-574.

JIANG AW, RANASINGHE R AND COWELL P. 2012. Contemporary hydrodynamics and morphological change of a microtidal estuary: a numerical modelling study. Ocean Dyn 63: 21-41. 
LEÃO ZMAN. 2002. Abrolhos, BA - O complexo recifal mais extenso do Atlântico Sul. In: Schobbenhaus C et al. (Eds), Sítios geológicos e paleontológicos do Brasil. DNPM/CPRM - Comissão Brasileira de Sítios Geológicos e Paleobiológicos (SIGEP), p. 345-359.

LESSA GC AND CIRANO M. 2006. On the Circulation of a Coastal Channel Within the Abrolhos Coral-Reef System - Southern Bahia (1740' S), Brazil. J Coast Res 2004: 450-453.

MAZDA Y, KANAZAWA N AND WOLANSKI E. 1995. Tidal asymmetry in mangrove creeks. Hydrobiologia 295: 51-58.

MMA/SRH. 1997. Ministério do Meio Ambiente/Secretaria de Recursos Hídricos. Plano diretor de recursos hídricos da bacia do extremo sul. Volume 6. Documento Síntese. Governo do Estado da Bahia. Superintendência de Recursos Hídricos. Salvador.

MOORE RD, WOLF J, SOUZA AJ AND FLINT SS. 2009. Morphological evolution of the Dee Estuary, Eastern Irish Sea, UK: A tidal asymmetry approach. Geomorphology 103: 588-596.

PARKER BB. 1991. The relative importance of the various nonlinear mechanisms in a wide range of tidal interactions (Review). In: Parker BB (Ed), Tidal hydrodynamics. J Wiley \& Sons, New York, p. 237-268.

PAWLOWICZ R, BEARDSLEY B AND LENTZ S. 2002. Classical tidal harmonic analysis including error estimates in MATLAB using T_TIDE. Comput Geosci 28: 929-937.

PEREIRA MD, SIEGLE E, MIRANDA LB AND SCHETTINI CAF. 2010. Hidrodinâmica e transporte de material particulado em suspensão sazonal em um estuário dominado por maré: Estuário de Caravelas (BA). Rev Bras Geofis 28: 427-444.

POSTMA H. 1967. Sediment transport and sedimentation in the estuarine environment. Am Assoc Adv Sci Publ, p. 158-179.

PRITCHARD DW. 1955. Estuarine circulation patterns. Proc Am Soc Civ Eng 81: 1-11.

RIBEIRO LV, DUPONT H, BODEVAN EC AND LÚCIO OS. 2000. Direção de transporte sedimentar na desembocadura do rio Itanhém, extremo sul da Bahia. Aplicação do método de Gao \& Collins e krigagem vetorial. Geonomos 8: 9-18.

RIDDERINKHOF H. 1997. The effect of tidal asymmetries on the net transport of sediments in the Ems Dollard estuary. J Coast Res, p. 41-48.

SCHETTINI CAF, PEREIRA MD, SIEGLE E, MIRANDA LB AND SILVA MP. 2013. Residual fluxes of suspended sediment in a tidally dominated tropical estuary. Cont Shelf Res 70: 27-35.

SCHETTINI CAF AND MIRANDA LB. 2010. Circulation and suspended particulate matter transport in a tidally dominated estuary: caravelas estuary, Bahia, Brazil. Brazilian J Oceanogr 58: 1-11.

SCHETTINI CAF AND TRUCCOLO EC. 1999. Tidal-driven influences on the shape of an estuarine salt wedge: ItajaíAçu river, South Brazil. In: Symposium on Tidal Action, Tidal Processes and Tidal Efects on Coastal Evolution, VII Brazilian Association for Quaternary Studies (ABEQUA), Porto Seguro, Brazil, 03-09 Outubro.

SOUSA SHM ET AL. 2014. Environmental Evolution of the Caravelas Estuary (Northeastern Brazilian Coast, $17^{\circ}$ $\mathrm{S}, 39^{\circ} \mathrm{W}$ ) Based on Multiple Proxies in a Sedimentary Record of the Last Century. J Coast Res 295: 474-486.

SPEER PE AND AUBREY DG. 1985. A study of non-linear tidal propagation in shallow inlet/estuarine systems Part II: Theory. Estuar Coast Shelf Sci 21: 207-224.

VAN DE KREEKE J AND DUNSBERGEN DW. 2000. Tidal asymmetry and sediment transport in the Frisian Inlet. In: Yanagi T (Ed), Interactions Between Estuaries, Coastal Seas and Shelf Seas. Terra Scientific Publishing Company, Tokyo, p. 139-159

WANG ZB, JEUKEN MCJL, GERRITSEN H, VRIEND HJ AND KORNMAN BA. 2002. Morphology and asymmetry of the vertical tide in the Westerschelde estuary. Cont Shelf Res 22: 2599-2609.

WILLMOTT C. 1981. On the validation of models. Phys Geogr 2: 184-194.

WRIGHT J, COLLING A AND PARK D. 1999. Open University. Waves, tides and shallow water processes, $2^{\text {nd }}$ ed., Open University, Oxford, 227 p. 